\title{
Endogenous islet uncoupling protein-2 expression and loss of glucose homeostasis in ob/ob mice
}

\author{
Monique C Saleh, Michael B Wheeler ${ }^{1}$ and Catherine B Chan \\ Department of Biomedical Sciences, University of Prince Edward Island, 550 University Avenue, Charlottetown, Prince Edward, C1A 4P3 Canada \\ ${ }^{1}$ Departments of Physiology and Medicine, University of Toronto, Toronto, Ontario, M5S 1A8 Canada \\ (Requests for offprints should be addressed to C B Chan; Email: cchan@upei.ca)
}

\begin{abstract}
We hypothesized that the loss of glucose homeostasis in $o b / o b$ mice is associated with upregulation of islet uncoupling protein-2 (UCP2) expression, leading to impaired glucosestimulated insulin secretion (GSIS). Changes in glucose homeostasis in lean and $o b / o b$ mice from 5 to 16 weeks were assessed by fasting blood glucose, plasma insulin, oral glucose tolerance, and tissue insulin sensitivity. In vitro GSIS and ATP content were assayed in isolated islets, while UCP2 expression was determined by quantitative real-time PCR and immunoblotting. Short-term reduction of UCP2 expression was achieved through transfection of islets with specific small interfering RNA. Insulin resistance was detected in 5-week-old ob/ob mice, but GSIS and blood glucose levels remained normal. By 8 weeks of age, $o b / o b$
\end{abstract}

mice displayed fasting hyperglycemia, hyperinsulinemia and glucose intolerance, and also had elevated non-esterified fatty acid concentration in plasma. In vitro, GSIS and ATP generation were impaired in $o b / o b$ islets. Islet UCP2 expression was elevated at 5 and 8 weeks of age. Short-term knockdown of islet UCP2 increased GSIS in islets of lean mice, but had no effect in islets from $o b / o b$ mice. Loss of glucose homeostasis and impairment of insulin secretion from isolated islets at 8 weeks in $o b / o b$ mice is preceded by an increase in UCP2 expression in islets. Moreover, the glucolipotoxic conditions observed are predicted to increase UCP2 activity, contributing to lower islet ATP and GSIS.

Journal of Endocrinology (2006) 190, 659-667

\section{Introduction}

Uncoupling protein-2 (UCP2), an endogenous negative regulator of insulin secretion (Saleh et al. 2002), is implicated in the insulin insufficiency of type 2 diabetes in rodents (Zhang et al. 2001, Joseph et al. 2002), because of its upregulation by fat (Chan et al. 2001, Joseph et al. 2002). Consequently, the increased uncoupling of oxidative phosphorylation results in the dissipation of the mitochondrial membrane gradient (Fink et al. 2002), lower cellular ATP, impaired ATP-dependent potassium $\left(\mathrm{K}_{\mathrm{ATP}}\right)$ channel closure, and reduced glucose-stimulated insulin secretion (GSIS; Chan et al. 2001, Lee et al. 2004). Polymorphisms in the ucp 2 promoter that increase its transcription are associated with impaired $\beta$-cell function and glucose intolerance in humans (Sesti et al. 2003). Additionally, the overexpression of several different genes in $\beta$-cells, including phospholipase A2 (Milne et al. 2005), hormone sensitive lipase (Sorhede Winzell et al. 2003), hepatocyte nuclear factors $4 \alpha$ and $1 \alpha$ (Wang et al. 2000a, 2000b), peroxisome-proliferator activated receptors (PPAR) $-\alpha$ and $-\gamma$ (Tordjman et al. 2002, Ito et al. 2004), and sterol response element-binding protein-1c (Yamashita et al. 2004) leads to the induction of UCP2 and suppression of GSIS. Conversely, the induction of Sirt1 in $\beta$-cells improves GSIS coincident with the downregulation of UCP2 (Moynihan et al. 2005). However, an important unanswered question is whether the upregulation of endogenous UCP2 coincides developmentally with loss of glucose homeostasis in diabetic models.

In several obese-diabetic rodent models examined in adulthood (Kassis et al. 2000, Laybutt et al. 2002), including the $o b / o b$ mouse (Zhang et al. 2001), islet UCP2 mRNA or protein expression is elevated. Insulin secretion in $o b / o b$ mice is elevated but nonetheless insufficient to maintain euglycemia (Zhang et al. 2001). Although increased UCP2 is predicted to contribute to the reduction in GSIS, there is little direct evidence to support this hypothesis. However, when $u c p 2$ is eliminated in $o b / o b$ mice by crossing them with ucp 2 knockout mice, first phase insulin secretion is increased and hyperglycemia is reduced (Zhang et al. 2001). No longitudinal studies examining concurrent changes in GSIS with UCP2 protein expression have yet been reported. It is also unclear how short-term reduction of UCP2 affects insulin secretion.

The ob/ob mouse develops mild type 2 diabetes by $8-9$ weeks of age, but then demonstrates a phenotypic improvement by $4-5$ months of age (Garthwaite et al. 1980, Menahan 1983, Tassava et al. 1992). Leptin induces UCP2 expression in 
islets (Shimabukuro et al. 1997), yet in the ob/ob mouse the upregulation of UCP2 (Zhang et al. 2001) is clearly independent of leptin. Other factors, such as non-esterified fatty acid (NEFA) may be important regulators of UCP2 transcription and activity in the $\beta$-cell (Lameloise et al. 2001, Medvedev et al. 2002, Koshkin et al. 2003). We hypothesized that the developmental loss of insulin secretion capacity would coincide with changes in UCP2 expression in $o b / o b$ mice. Thus, UCP2 mRNA and protein expression were correlated with metabolic indices and GSIS in 5-, 8- and 16-week-old $o b / o b$ and lean mice. In addition, the effect of acutely reducing UCP2 expression by $\sim 50 \%$ on GSIS was examined.

\section{Materials and Methods}

Animals and in vivo protocols

Control $(\mathrm{C} 57 \mathrm{Bl} / 6)$ and obese $(o b / o b)$ female mice obtained from Jackson Laboratories (Bar Harbor, ME, USA) were fed standard rodent chow (Purina 5001; St Louis, MO, USA) and water ad libitum and were housed under standard temperature and light-controlled conditions. All protocols were approved by the University of Prince Edward Island Animal Care Committee, following the Guidelines of the Canadian Council on Animal Care.

Body weights were measured at 5, 8 and 16 weeks of age. Insulin tolerance tests were performed after a $4 \mathrm{~h}$ fast, as described (Zhang et al. 2001) in ob/ob mice from all age groups. Lean mice from the 16 -week age group served as controls. In a second group of overnight-fasted mice, glucose tolerance and in vivo insulin secretion were assessed following i.p. injection of glucose (Joseph et al. 2002).

Prior to islet isolation, mice were fasted for $4 \mathrm{~h}$, then anesthetized with pentobarbital $(60 \mathrm{mg} / \mathrm{kg}$ i.p.). A $\sim 0.5 \mathrm{ml}$ blood sample was obtained by cardiac puncture for measurement of serum NEFA (Roche Diagnostics, Laval, QC, Canada), triglyceride (TG; Sigma), and insulin (Crystal Chem, Chicago, IL, USA).

\section{Islet isolation, culture, and insulin secretion and ATP studies}

Islets were isolated as described (Zhang et al. 2001) and cultured overnight in Dulbecco's modified Eagle medium (DMEM) containing $8.3 \mathrm{mmol} / 1$ glucose (Kibenge \& Chan 1995), unless otherwise indicated. For measurement of insulin secretion under static conditions, the culture medium was replaced with $1.0 \mathrm{ml}$ DMEM plus $0.1 \%$ gelatin and glucose concentrations as indicated in the figures. Insulin release and islet insulin content were measured by RIA, using human insulin as standard. For ATP measurement, islets were transferred to fresh DMEM containing $2.8 \mathrm{mmol} / 1$ glucose and $0 \cdot 1 \%$ gelatin for $30 \mathrm{~min}$ at $37^{\circ} \mathrm{C}$, centrifuged and the medium aspirated. Islets were then incubated in DMEM containing $2 \cdot 8$ or $16.5 \mathrm{mmol} / 1$ glucose for $60 \mathrm{~min}$ at $37^{\circ} \mathrm{C}$.
Following centrifugation, the islet pellets were lysed with $100 \mu \mathrm{l}$ ATP lysis buffer (ATP-Lite, Perkin-Elmer, Boston, MA, USA) and frozen at $-80{ }^{\circ} \mathrm{C}$ until assayed for ATP content using the ATP-Lite kit. Protein content of each sample was determined using the Lowry method (Sigma).

\section{Knockdown of ucp2 gene expression}

Small interfering RNA (siRNA) against ucp2 mRNA (siUCP2) and control constructs (siControl) were purchased from Ambion (Austin, TX, USA). In a pilot study, the optimal dose of siUCP2 resulting in $\sim 50 \%$ knockdown of UCP2 protein expression was determined (not shown). The siRNAs were transfected into intact islets from 8-week-old rats at a dose of 25 pmol per 100 islets with the transfection agent $\mathrm{N}$-(2,3-dioleoyloxy-1-propyl)trimethylammonium methyl sulfate (DOTAP; Sigma) following the suggested protocol (Lakey et al. 2001). The islets were harvested $48 \mathrm{~h}$ following transfection for insulin secretion experiments or measurement of UCP2 expression.

\section{Determination of islet UCP2 and PPAR $\alpha$ expression}

After overnight culture, total RNA was extracted from 100 islets per mouse using Trizol (Invitrogen), and cDNA was created using oligo-dT primers and the Cloned AMV First Strand cDNA Synthesis Kit (Invitrogen). The ucp2-specific primer sequences for quantitative PCR (qPCR) were reported elsewhere (Joseph et al. 2002). For normalization, $\beta$-actin primers were utilized. Gene expression was quantified using SYBR Green ready-mix for qPCR (Invitrogen). Standards and samples were heated at $95^{\circ} \mathrm{C}$ for $10 \mathrm{~min}$, followed by 40 cycles at $95^{\circ} \mathrm{C}$ for $10 \mathrm{~s}$, annealing at $57^{\circ} \mathrm{C}$ for $30 \mathrm{~s}$, and extension at $72^{\circ} \mathrm{C}$ for $20 \mathrm{~s}$ using a Rotor-Gene qPCR thermocycler (Corbett Research, Sydney, Australia). Relative quantities of qPCR product were determined by comparison to standard curves constructed from a dilution series of a cDNA sample mixture. Melt curve analysis for each primer set revealed only one peak for each product. The size of the qPCR products was confirmed by comparing the size of product with a commercial ladder after agarose gel electrophoresis.

For UCP2 protein expression, 100 islets per sample (cultured overnight) were lysed in LIPA buffer $(25 \mathrm{mM}$ Tris-HCl, $\mathrm{pH} 7 \cdot 4,0 \cdot 1 \%$ SDS, $0 \cdot 1 \%$ Triton $\mathrm{X}-100,1 \%$ sodium deoxycholate, $150 \mathrm{mM} \mathrm{NaCl}, 1 \mathrm{mM}$, EDTA, $1 \mathrm{mM}$ $\mathrm{Na}_{3} \mathrm{VO}_{4}, 1 \mathrm{mM}$ PMSF, $10 \mu \mathrm{g} / \mathrm{mL}$ aprotinin and $5 \mu \mathrm{g} / \mathrm{mL}$ leupeptin Kim et al. 2004). Lysate proteins were separated by 10\% PAGE and transferred to nitrocellulose membranes (BioRad). Primary antibodies for UCP2 (Santa Cruz Biotechnology, Santa Cruz, CA, USA; 1:2500), PPAR $\alpha$ (Affinity Bio Reagents/Cedarlane, Hornby, ON, Canada; 1:500), and $\beta$-actin (Sigma; $1: 10000$ ) were applied for $24 \mathrm{~h}$ at $4{ }^{\circ} \mathrm{C}$. Membranes were then exposed to appropriate peroxidase conjugated secondary antibodies (1:5000) for $2 \mathrm{~h}$ at room temperature. Proteins of interest were detected using 
enhanced chemiluminescence (Amersham) and imaged on a Kodak Image Station.

\section{Statistical analysis}

All data are expressed as means \pm s.E.M. Significant differences at $P<0.05$ were determined using unpaired $t$-test or twoway ANOVA followed by Bonferroni post hoc tests, where appropriate.

\section{Results}

\section{Metabolic profile of $\mathrm{ob} / \mathrm{ob}$ mice}

Metabolic profile summaries are provided in Table 1. Obese mice weighed $0 \cdot 5$ - and $2 \cdot 5$-fold more than lean mice at age 5 and 16 weeks of age respectively $(P<0 \cdot 0001$ for phenotype; $P<0 \cdot 0001$ for age; $P<0 \cdot 0001$ for phenotype $X$ age). Blood glucose concentrations were elevated $(P<0 \cdot 05)$ in the 8 -week-old $o b / o b$ mice, but not the 5- or 16-week-old $o b / o b$ mice compared with lean controls. At 5 weeks, plasma insulin was ninefold higher in $o b / o b$ than lean mice. At 8 weeks, insulin secretion was increased by 30-fold compared with lean mice $(P<0 \cdot 001)$. The insulin:glucose (ins:gluc) ratio is an approximate measure of insulin resistance; the higher the ratio, the more insulin is required to maintain appropriate glucose concentrations. Ins:gluc was constant in lean mice but decreased significantly by $32 \%$ with increasing age in $o b / o b$ mice $(P<0 \cdot 05)$. Serum NEFA concentrations were elevated in 8 - and 16 -week-old ob/ob mice $(P<0 \cdot 05)$. A significant difference in serum TG between phenotypes was detected only at 16 weeks of age $(P<0 \cdot 05)$.

Glucose tolerance tests were performed in 8-week-old mice when hyperglycemia was apparent (Fig. 1A). Fasting glucose concentrations exceeded $13 \mathrm{mmol} / 1$ in $\mathrm{ob} / \mathrm{ob}$ mice, compared with $\sim 5.5 \mathrm{mmol} / \mathrm{l}$ in lean mice $(P<0 \cdot 01)$. Circulating glucose concentrations in $o b / o b$ mice peaked at $\sim 34 \mathrm{mmol} / 130 \mathrm{~min}$ after glucose administration, then declined to fasting concentrations by $2 \mathrm{~h}$. Peak glucose concentrations of $\sim 12 \mathrm{mmol} / 1$ occurred $15 \mathrm{~min}$ after administration in lean mice. Fasting plasma insulin concentrations were 15-fold higher in $o b / o b$ than lean mice $(P<$ $0 \cdot 0001$, Fig. 1B). The $o b / o b$ mice had profoundly impaired GSIS in vivo, with no significant differences in concentration observed over the $2-\mathrm{h}$ period. Lean mice exhibited a rapid $2 \cdot 2$-fold increase in insulin secretion within $5 \mathrm{~min}$ of glucose administration, returning to baseline by $30 \mathrm{~min}$ (inset of Fig. 1B).

Insulin tolerance tests were carried out to determine if the age-related changes in glucose tolerance (as measured by the ins:gluc ratio, Table 1) of $o b / o b$ mice were related to changes in tissue insulin sensitivity. The 16-week-old lean mice were more sensitive to insulin than $o b / o b$ mice in any age grouping (Fig. 1C, $P<0 \cdot 001$ ). There was no effect of age on the insulin tolerance of $o b / o b$ mice.

\section{Islet and insulin secretion characteristics}

Islet enlargement, as indicated by islet insulin content, was not present at 5 weeks of age. At both 8 and 16 weeks of age, the insulin content of $o b / o b$ islets was approximately twofold greater than lean islets $(P<0 \cdot 05$, Table 1$)$.

When expressed as percentage of islet content, basal insulin secretion (at $2 \cdot 8 \mathrm{mmol} / \mathrm{l}$ glucose) was significantly elevated in isolated islets from 8 - and 16-week-old $o b / o b$ mice compared with lean animals (Fig. 2B and C; $P<0 \cdot 05$ ) but not in 5-week-old mice (Fig. 4A). Absolute insulin secretion was elevated approximately four- to fivefold in the older groups (insets of Fig. 2B and C). Lean islets incubated with 11$22 \mathrm{mmol} / \mathrm{l}$ glucose had insulin secretion elevated by four- to sevenfold over basal in all age groups. In contrast, GSIS was observed only at 5 weeks of age in the $o b / o b$ mice (Fig. 2A). In vivo fasting glucose concentrations were also considered in the analysis of in vitro data. Data from the glucose tolerance tests showed that fasting glucose in lean mice was $\sim 5.5 \mathrm{mmol} / 1$ compared with $>13 \mathrm{mmol} / 1$ in $\mathrm{ob} / \mathrm{ob}$ mice (indicated on Fig. 2B by arrows). In lean islets, raising glucose from 5 to $22 \mathrm{mmol} / 1$ increased insulin secretion from 3 to $7 \cdot 5 \%$ of total content. In comparison, when glucose increased from 11 to $22 \mathrm{mmol} / \mathrm{l}$ in $o b / o b$ mouse islet incubations, the insulin secretion was nearly constant (from 4 to $4 \cdot 5 \%$ of total content).

\section{Islet ATP content}

ATP content of isolated, overnight-cultured islets was measured in 8-week-old mice (Fig. 3), concurrent with the onset of impaired glucose homeostasis. Lean islets had a fivefold increase in ATP content in high compared with low glucose $(P<0 \cdot 05)$. In contrast, $o b / o b$ islets had elevated ATP at low glucose $(P<0 \cdot 05$ compared with lean islets $)$ but failed to exhibit a significant increase when exposed to higher glucose.

\section{UCP2 expression}

Ucp 2 mRNA expression was measured by qPCR at 5, 8 and 16 weeks of age. Significant effects of age $(P=0 \cdot 0014)$, genotype $(P=0 \cdot 0028)$, and an age $\times$ genotype interaction were detected $(P=0 \cdot 0009)$. The amount of $u c p 2 \mathrm{mRNA}$, relative to $\beta$-actin, declined by $60 \%$ from 5 to 16 weeks of age in lean islets (Fig. 4A). At 5 weeks of age, $o b / o b$ and lean islet UCP2 expressions were similar, but $o b / o b$ mice aged 8 or 16 weeks had approximately twofold higher islet $u c p 2$ mRNA expression than lean controls $(P<0 \cdot 05)$.

UCP2 (Fig. 4B) protein expression was quantified by Western blotting. UCP2 expression in $o b / o b$ islets was increased relative to lean islets at age $5(P=0 \cdot 004)$ and 8 weeks $(P<0 \cdot 01)$ but not at 16 weeks of age. Because the activation of PPAR $\alpha$ is reported to induce UCP2 expression, Western blotting for PPAR $\alpha$ was also conducted (Fig. 4C). 


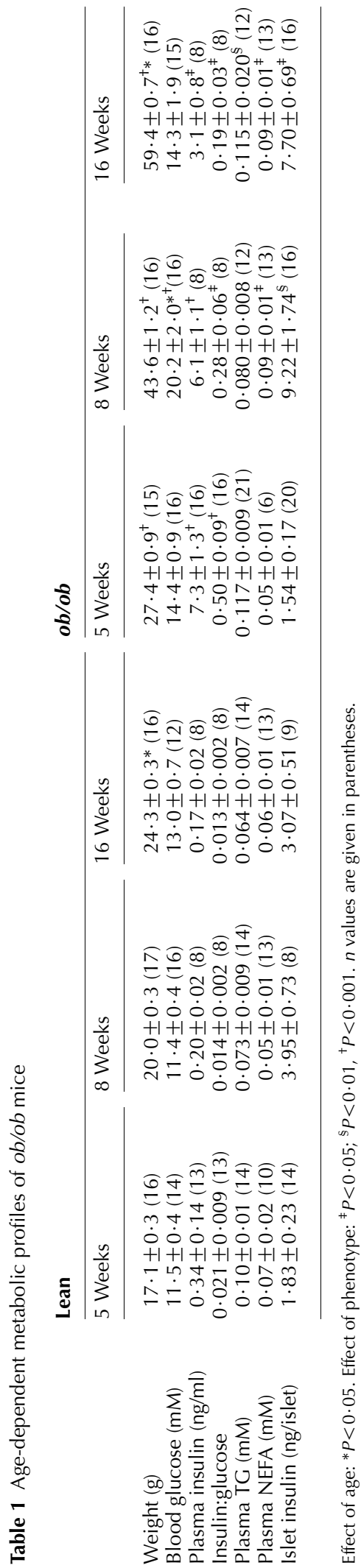

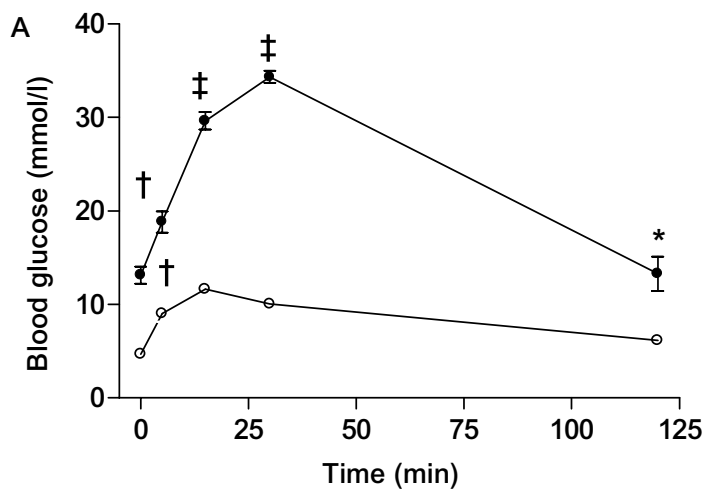
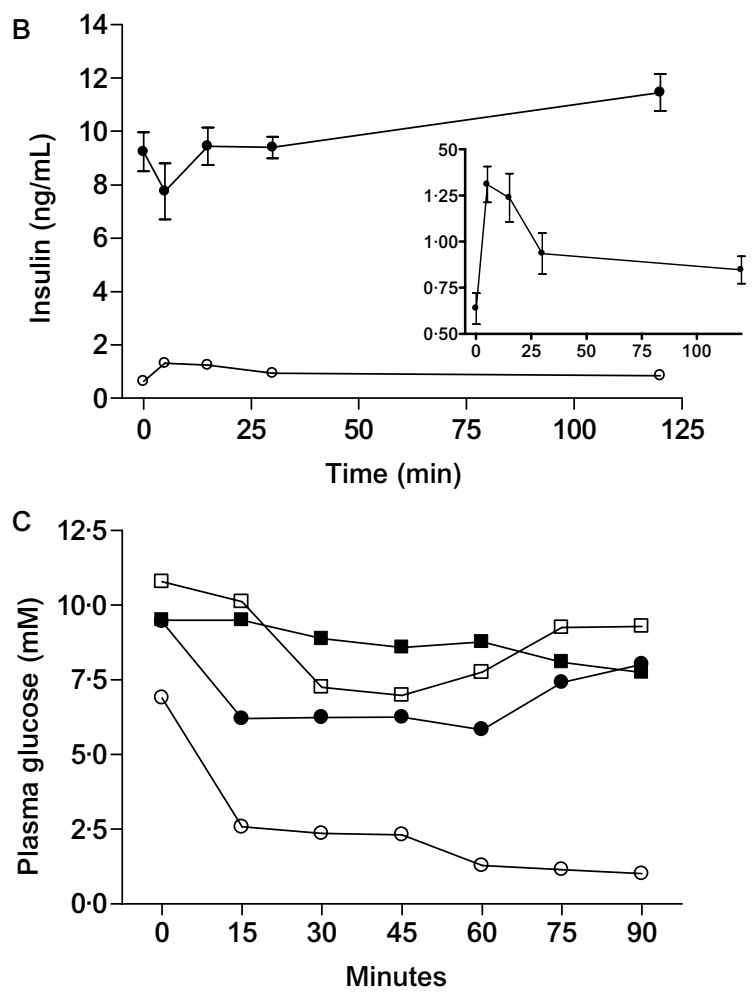

Figure 1 Intraperitoneal glucose tolerance tests conducted in $o b / o b$ $(\boldsymbol{O}, n=6)$ and lean mice $(O, n=7)$ to determine the incremental change in (A) blood glucose and (B) plasma insulin. Animals were overnight fasted prior to administration of $1 \mathrm{~g} / \mathrm{kg}$ glucose, i.p. Blood glucose concentrations were significantly higher in $o b / o b$ than lean mice at all time points $\left({ }^{*} P<0 \cdot 05,{ }^{\dagger} P<0 \cdot 01,{ }^{\ddagger} P<0 \cdot 001\right)$. Plasma insulin concentrations were higher in $o b / o b$ mice than lean mice at all time points $(P<0 \cdot 001$ for all). The inset in B shows the pattern of insulin responsiveness to glucose for the lean mice, with s.E. of the measurements indicated. (C) Insulin tolerance test results in 16-weekold lean $(\bigcirc)$ and $5(\bullet), 8(\square)$ and 16-week old ob/ob mice ( $)$. Blood samples were obtained from the tail vein of 4-h fasted mice. Mice were injected with $1 \mathrm{U} / \mathrm{kg}$ human insulin at time $=0 . n=7-8$. There was no significant effect of age on the insulin tolerance of $o b / o b$ mice. 

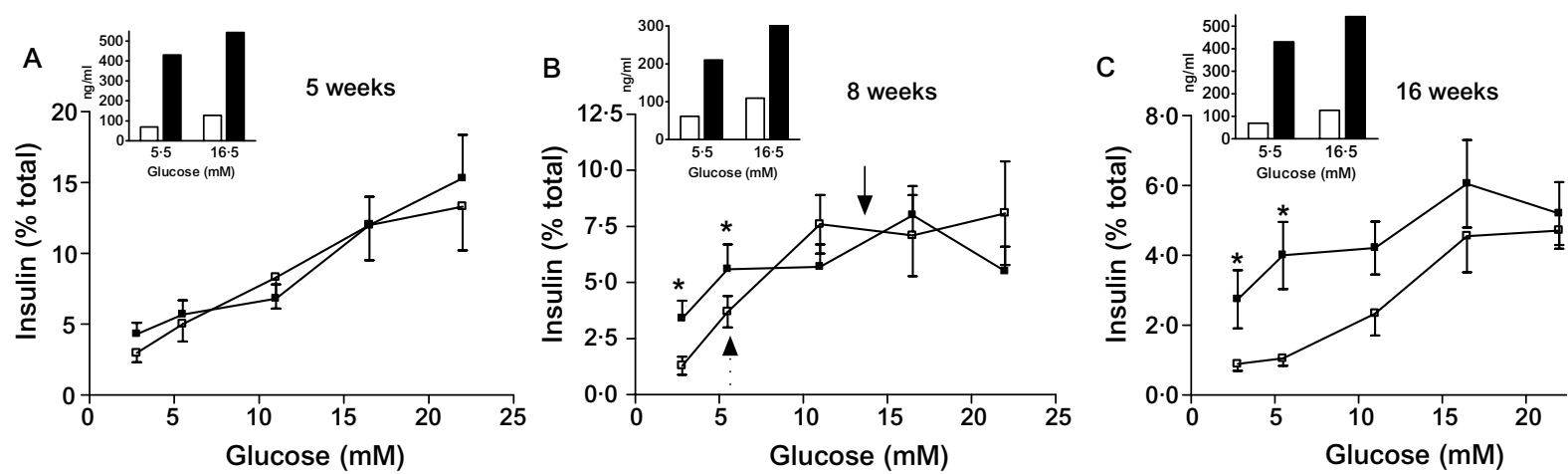

Figure 2 Glucose-stimulated insulin secretion (GSIS) from isolated islets. (A)-(C) illustrate GSIS $(2 \cdot 8-22 \cdot 0 \mathrm{mM})$, expressed as a percentage of islet insulin content, in islets isolated from lean $(\square, n=7-14)$ and $o b / o b(\mathbf{\square}, n=20-21)$ mice from 5 to 16 weeks of age. ${ }^{*} P<0 \cdot 0001$ for phenotype effect. The insets show the mean absolute insulin secretion measured at $5 \cdot 5$ and $16 \cdot 5 \mathrm{mM}$ glucose. At 8 weeks of age, the mean fasting blood glucose concentration, taken from i.p. glucose tolerance experiments, is indicated by the dashed arrow (lean) and closed arrow $(o b / o b)$.

Expression of $\operatorname{PPAR} \alpha$ protein was similar in $o b / o b$ and lean islets at 8 weeks of age.

\section{Effects of UCP2 knockdown on insulin secretion}

Following transfection of siUCP2 or siControl vectors for $48 \mathrm{~h}$, protein expression of UCP2 was quantified by Western blotting for lean (Fig. 5A) and ob/ob islets (Fig. 5B). In both cases, siControl had no effect on UCP2 expression, whereas siUCP2 transfection reduced UCP2 expression by $40-50 \%$ $(P<0 \cdot 05)$.

The effects of $50 \%$ knockdown of UCP2 expression on GSIS were then assessed. Lean siUCP2-transfected islets had significantly higher insulin secretion than either untransfected or siControl transfected islets (Fig. 5C, $P<0 \cdot 01$ ). In contrast, siUCP2 transfection had no significant effect on GSIS from $o b / o b$ islets (Fig. 5D). Neither siUCP2 nor siControl vector transfection had any effect on islet insulin content (Fig. 5E and F).

\section{Discussion}

A physiological role for UCP2 in pancreatic $\beta$-cells has not been established. It is also unclear whether UCP2 is a causal factor in $\beta$-cell dysfunction, although its absence is clearly associated with protection from lipotoxicity (Joseph et al. 2002, 2004) and reactive oxygen species (ROS; Krauss et al. 2003). We examined age-dependent changes in glucose homeostasis and UCP2 expression in $o b / o b$ mice, in order to establish the potential contribution of UCP2 to the development of insulin insufficiency and diabetes.

The long-term absence of leptin, as experienced by the $o b / o b$ mouse, would be expected to elevate insulin secretion (Ceddia et al. 2002). Leptin regulates expression of genes involved in $\beta$-cell fatty acid metabolism and also induces ucp 2 transcription in rat islets (Zhou et al. 1997). However, in the $o b / o b$ mouse, the regulation of UCP2 must be independent of leptin. Other factors, such as NEFA, may be important regulators of UCP2 expression and activity in the $\beta$-cell (Lameloise et al. 2001, Koshkin et al. 2003). Since UCP2 induction by overexpression strategies inhibits GSIS, it is important to determine whether impaired insulin response of islets and glucose intolerance in diabetes is associated with an increase in endogenous UCP2.

The present study reiterates the classical pattern of development of insulin resistance and diabetes in $o b / o b$ mice (Garthwaite et al. 1980, Menahan 1983, Tassava et al. 1992). The earliest phenotypical changes were weight gain, insulin resistance and hyperinsulinemia at 5 weeks of age. $\beta$-cell function and insulin content were normal, as was islet $u c p 2$ mRNA expression. However, by 8 weeks of age the $o b / o b$ mice exhibited glucose intolerance with marked fasting hyperinsulinemia and loss of GSIS in vivo and in vitro. Fasting hyperinsulinemia may be partially attributed to islet hyperplasia and hypertrophy, given the $2 \cdot 5$-fold increase in insulin content per islet but is also consistent with the toxic effects of

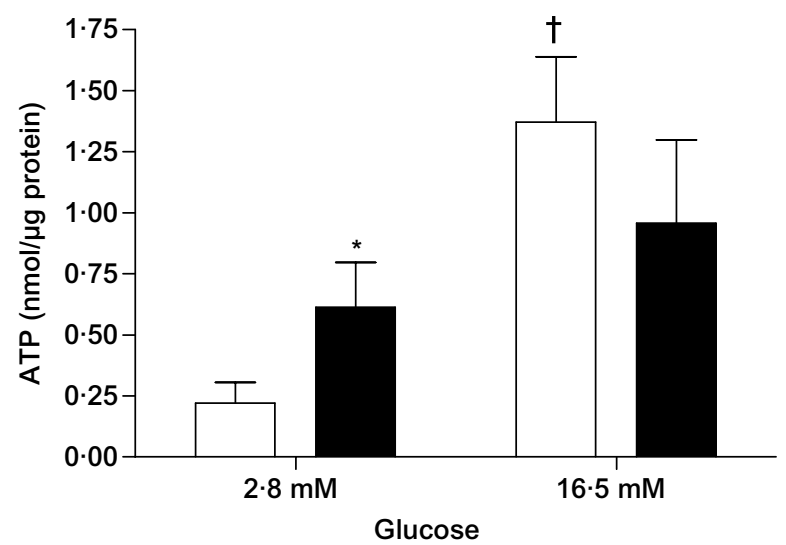

Figure 3 Quantification of ATP content (normalized to islet total protein) in islets from lean $(\square)$ and $o b / o b(\square)$ mice at 8 weeks of age. Islets were exposed to either $2 \cdot 8$ or $16 \cdot 5 \mathrm{mM}$ glucose for 60 min prior to ATP measurement. ${ }^{*} P<0.05$ for effect of phenotype; ${ }^{\dagger} P<0 \cdot 01$ for effect of glucose. 


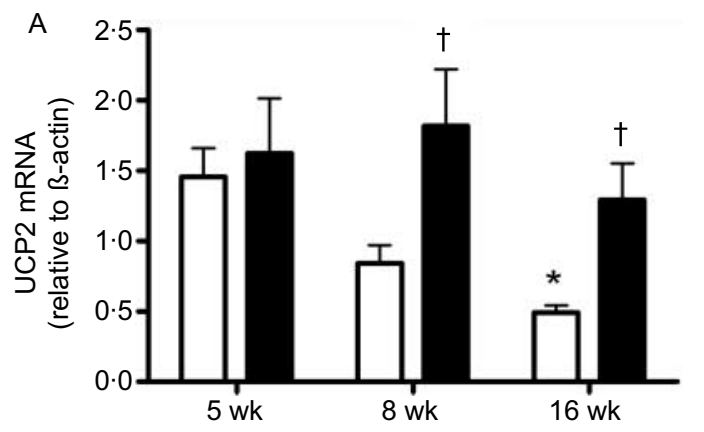

B
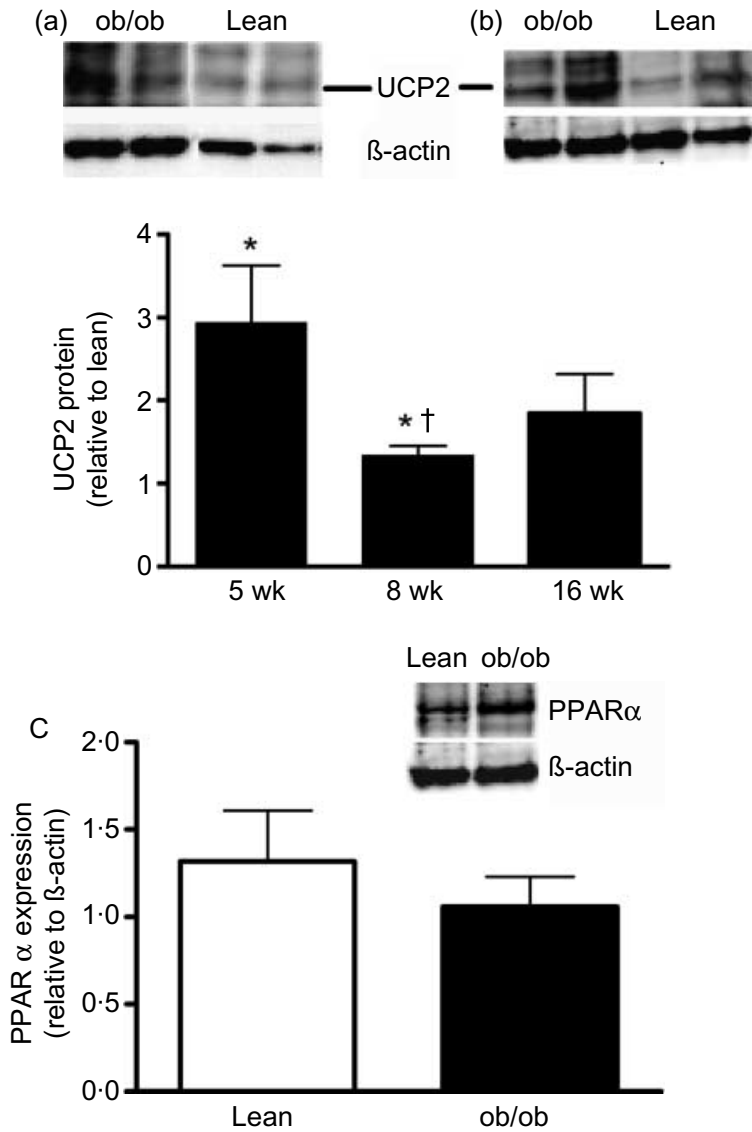

Figure 4 Expression of UCP2 in $o b / o b$ islets. (A) Pancreatic islet UCP2 mRNA expression relative to $\beta$-actin in lean $(\square, n=7-21)$ and $o b / o b$ mice $(\boldsymbol{\square}, n=8-18)$ at 5,8 , and 16 weeks of age. Expression of mRNA was measured by qPCR and normalized to $\beta$-actin, which was not different between lean and $o b / o b$ mice (not shown). ${ }^{*} P<0.05$ for effect of age; ${ }^{\dagger} P<0.05$ for effect of phenotype. (B) Analysis of Western blot data to quantify expression of pancreatic islet UCP2 $(n=5-9$ each). Insets (a) and (b) show representative blots for 5 - and 8 -week-old ob/ob and lean islet lysates. For each lane, UCP2 expression normalized to $\beta$-actin. Expression in $o b / o b$ islets was then expressed relative to UCP2 expression in lean islets. (C) PPAR $\alpha$ protein $(n=19$ and 23 for lean $(\square)$ and ob/ob ( $\square$ ) respectively) in 8-week-old mice. Data were normalized to $\beta$-actin. Insets show examples of typical blots.
NEFA (Carlsson et al. 1999). We observed increased islet ATP content (normalized to total protein) at low glucose, also seen after NEFA exposure of islets (Carlsson et al. 1999), which is consistent with increased glucokinase activity (Chan 1995) and $\mathrm{K}_{\text {ATP }}$ channel closure at lower glucose concentrations (Chan \& MacPhail 1996) found in other obese/diabetic rodents.

Fasting hyperinsulinemia with loss of GSIS is consistent with glucolipotoxicity, the term describing concurrent hyperglycemia and hyperlipidemia, which together impair $\beta$-cell function (Poitout \& Robertson 2002). Notably, 8 -week-old $o b / o b$ mice had elevated circulating NEFA in addition to hyperglycemia, thereby creating a glucolipotoxic condition. Exposing $\beta$-cells to NEFA with glucose $>5 \mathrm{mmol} / \mathrm{l}$ causes altered transcription of hundreds of genes, many associated with fatty acid metabolism (Wang et al. 2004). One such gene receiving considerable attention recently because of its putative involvement in the regulation of GSIS is ucp2 (Lameloise et al. 2001, Joseph et al. 2002, 2004, Patane et al. 2002). Our results showed that an increase in UCP2 protein was detectable at 5 and 8 weeks, whereas ucp 2 mRNA expression was elevated at 8 and 16 weeks. Therefore, the induction of UCP2 occurs prior to development of impaired GSIS and hyperglycemia, suggesting it may be a causal factor. The findings are also consistent with our previous work showing that knockout of $u c p 2$ in $o b / o b$ mice from conception partially corrects the diabetic phenotype.

The factors that induce UCP2 expression at this time are unknown; however, given the rapid growth of the $o b / o b$ mice during this timeframe, a generalized metabolic stress may contribute. Indeed, insulin resistance and hyperinsulinemia were already present at 5 weeks, indicative of a $\beta$-cell response to metabolic demand. At 8 weeks, the upregulation of $u c p 2$ mRNA in ob/ob mouse islets was not associated with increased PPAR $\alpha$ expression. The discordance between mRNA and protein expression of UCP2 suggest that posttranscriptional regulation of mRNA activity or turnover strongly influences protein induction. Other researchers (Pecqueur et al. 2001) previously showed that UCP2 protein is less ubiquitously expressed in tissues than its mRNA. These data confirm that UCP2 protein translation is tightly regulated and may not parallel changes in mRNA transcription as was found in the brain (Ho et al. 2005). Interestingly, in the $d b / d b$ mouse, the reduction of plasma glucose concentrations normalized GSIS but ucp 2 mRNA expression remained elevated (Kjorholt et al. 2005), another example of dissociation of UCP2 mRNA expression and insulin secretion. It has been wondered why UCP2 is expressed in $\beta$-cells when its presence can be detrimental to insulin secretion, but it appears that a strong stimulus is required to elicit upregulation of UCP2 protein and that temporal regulation may occur. For example, the overexpression of hormone-sensitive lipase by $\sim 50$-fold in transgenic mice caused a marginal increase in UCP2 protein expression (not 

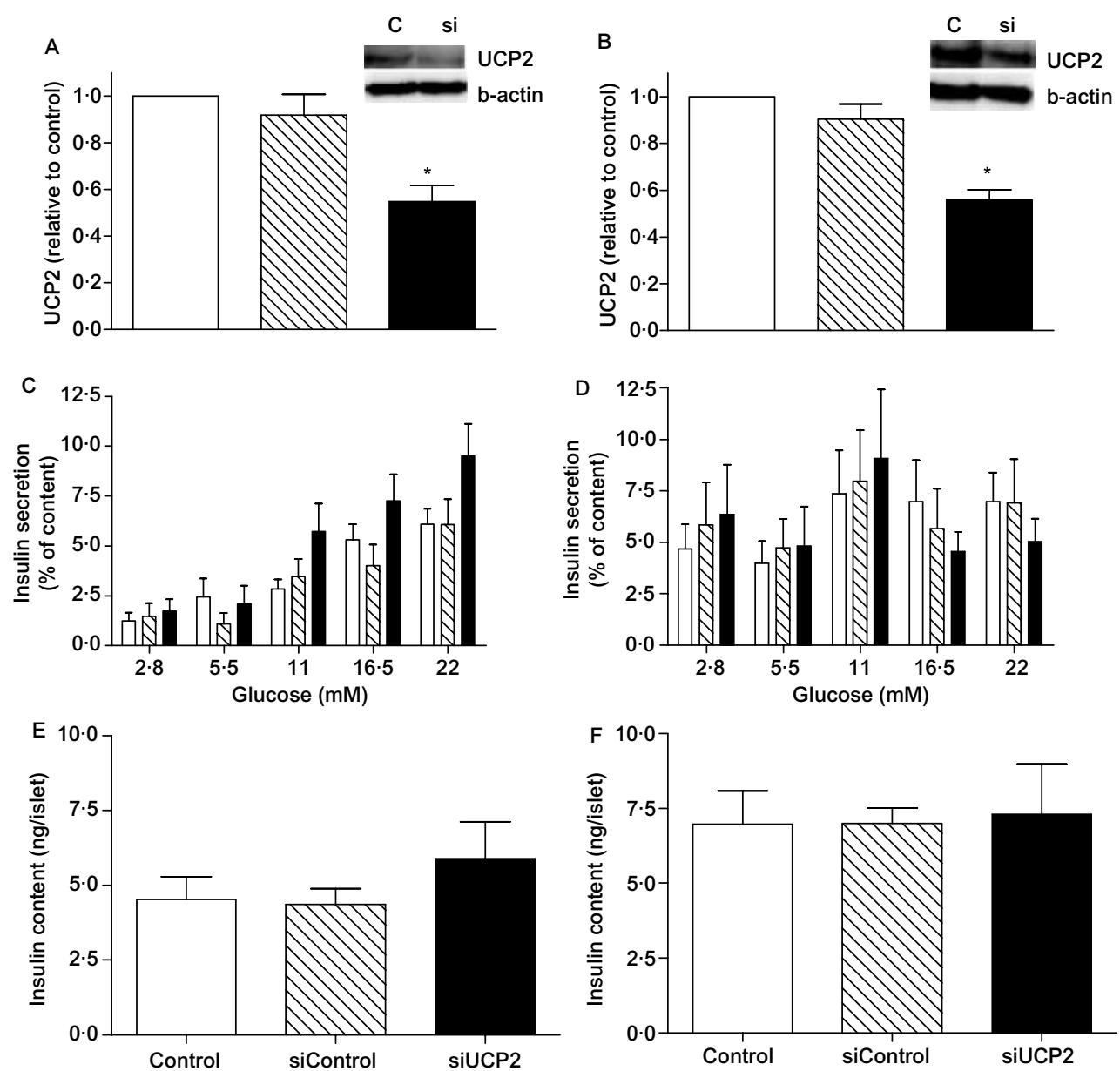

Figure 5 Effects of siUCP2 on UCP2 protein expression in 8-week-old (A) lean $(n=4)$ and (B) ob/ob islets $(n=3)$, measured by Western blotting $48 \mathrm{~h}$ following transfection with $\mathrm{N}$-(2,3-dioleoyloxy-1propyl)trimethylammonium methyl sulfate. All data are expressed relative to untransfected control results after normalizing to $\beta$-actin. ${ }^{*} P<0 \cdot 05$ compared with lean untransfected controls. Insets are examples of typical blots. GSIS $48 \mathrm{~h}$ following siUCP2 transfection assessed in (C) lean, $n=10$ and (D) $o b / o b$ islets, $n=8$. SiUCP2 treatment ( $\mathbf{\square})$ significantly increased insulin secretion compared with untransfected controls $(\square)$ in lean islets $(P=0.0086$ by two way ANOVA). There was no significant difference in insulin secretion between untransfected control and siControl islets (hatched bars, $P=0 \cdot 4838)$. The effect of glucose was also significant in lean islets $(P<0 \cdot 0001)$. Compared with untransfected controls $(\square)$, islet insulin content (ng/islet) was not significantly affected by siUCP2 ( or siControl treatment (hatched bars) in (E) lean, $n=10$ or (F) ob/ob, $n=8$ islets.

quantified) vs a $1 \cdot 5$-fold induction of $u c p 2$ mRNA (Sorhede Winzell et al. 2003).

Lack of induction of UCP2 at later ages does not eliminate it as a potential cause of impaired GSIS in $o b / o b$ islets. In addition to regulating transcription (Medvedev et al. 2002), NEFA strongly activate the uncoupling action of UCP2 in $\beta$-cells by increasing ROS production (Koshkin et al. 2003). Notably, glucose-stimulated $o b / o b \quad \beta$-cells produce significantly more ROS than lean $\beta$-cells (Krauss et al. 2003). Thus, the glucolipotoxic environment is predicted to strongly induce uncoupling in $o b / o b \beta$-cells even if UCP2 expression is normal. The observation that glucose failed to increase ATP concentration in the ob/ob islets is consistent with the uncoupling of respiration. In $o b / o b$ hepatocytes, which express ucp2 (Rashid et al. 1999), proton leak is elevated compared with lean hepatocytes (Chavin et al. 1999, Porter et al. 1999), which do not express ucp2 (Rashid et al. 1999). In islets, reduced ATP production leads to impaired closure of $\mathrm{K}_{\text {ATP }}$ channels, thereby suppressing GSIS (Chan et al. 2001). Interestingly, muscle cells from insulin-resistant but nondiabetic human subjects exhibit reduced insulin-stimulated ATP synthesis (Petersen et al. 2005), pointing to the importance of adequate cellular energy to maintain function in a variety of cell types implicated in diabetes.

The present findings are at odds with our previous demonstration of elevated UCP2 in $o b / o b$ islets at 4 months of 
age (Zhang et al. 2001). The earlier experiments were performed in male mice. Effects of sex steroids on $u c p 2$ are apparently small in most tissues (Pedersen et al. 2001), but have not been studied in islets. Interestingly, our data indicate that $u c p 2$ mRNA expression declines with increasing age in lean but not $o b / o b$ mice. The elevation of $u c p 2$ mRNA seen in all postweaning mice may be an adaptation to the high fat diet preweaning, similar to the fatty acid-dependent post-natal increase in UCP3 transcription in skeletal muscle (Brun et al. 1999). Hyperlipidemia, caused by elevated fatty acid synthesis by liver and adipose by 8 weeks in $o b / o b$ mice (Kaplan \& Leveille 1981), may prevent further regression of $u c p 2$ mRNA.

Eliminating $u c p 2$ from the $o b / o b$ mouse genome (by crossing $l e p^{-1-}$ mice onto the $u c p 2^{-/-}$background) partially ameliorated in vivo glucose intolerance because of enhanced insulin secretion (Zhang et al. 2001). Moreover, a gene-dose effect of UCP2 was apparent, with mice heterozygous for UCP2 $\left(u c p 2^{+/-}\right)$secreting more insulin and having lower blood glucose than $u c p 2^{+/+}$mice (Zhang et al. 2001). Knockdown of UCP2 protein by $\sim 50 \%$ using a siRNA approach improved in vitro GSIS in lean islets in the present study, as anticipated. However, acute knockdown of UCP 2 by a similar amount in the $o b / o b$ islets failed to improve insulin secretion, suggesting that short-term reduction of UCP2, unless coupled with a return to normal of other genes, whose expression is altered in $o b / o b$ islets, inadequately regulates insulin secretion. To our knowledge, genetic profiling has not been done in islet tissue of $o b / o b$ vs lean mice. However, in one study of $o b / o b$ liver, $3 \%$ of $>5000$ unique cDNAs examined were consistently up- or downregulated (Ferrante et al. 2001). When insulin-secreting cells were treated with NEFA in culture, an average $5 \%$ of genes and expressed sequence tags were altered (Wang et al. 2004). Thus, it is not surprising that short-term reduction of a single gene failed to normalize GSIS, given that $o b / o b$ mice have existed without a functional leptin gene since conception, perhaps resulting in altered expression of $3-5 \%$ of $\beta$-cell genes.

These studies demonstrated a developmental relationship between UCP2 protein expression and impaired glucose homeostasis in ob/ob mice, with the induction of UCP2 preceding impairment of GSIS. Short-term knockdown of UCP2 did not elicit any improvement in GSIS in $o b / o b$ islets, although GSIS in lean islets was potentiated. These studies provide additional evidence that UCP2 modulates insulin secretion under physiological and pathophysiological conditions.

\section{Funding}

These studies were supported by the Canadian Institutes of Health Research (grant MOP 43987) to C B C. The authors declare that there is no conflicts of interest that would prejudice the impartiality of this work.

\section{References}

Brun S, Carmona MC, Mampel T, Vinas O, Giralt M, Iglesias R \& Villarroya F 1999 Activators of peroxisome proliferator-activated receptor-alpha induce the expression of the uncoupling protein- 3 gene in skeletal muscle: a potential mechanism for the lipid intake-dependent activation of uncoupling protein-3 gene expression at birth. Diabetes 48 1217-1222.

Carlsson C, Borg LA \& Welsh N 1999 Sodium palmitate induces partial mitochondrial uncoupling and reactive oxygen species in rat pancreatic islets in vitro. Endocrinology 140 3422-3428.

Ceddia RB, Koistinen HA, Zierath JR \& Sweeney G 2002 Analysis of paradoxical observations on the association between leptin and insulin resistance. FASEB Journal 16 1163-1176.

Chan CB $1995 \beta$-cell stimulus-secretion coupling defects in rodent models of obesity. Canadian Journal of Physiology and Pharmacology 73 1414-1424.

Chan CB \& MacPhail RM 1996 K $_{\text {ATP }}$ channel-dependent and -independent pathways of insulin secretion in isolated islets from $f a / f a$ Zucker rats. Biochemistry and Cell Biology 74 403-410.

Chan CB, De Leo D, Joseph JW, McQuaid TS, Ha XF, Xu F, Tsushima RG, Pennefather PS, Salapatek AM \& Wheeler MB 2001 Increased uncoupling protein-2 levels in beta-cells are associated with impaired glucosestimulated insulin secretion: mechanism of action. Diabetes 50 1302-1310.

Chavin KD, Yang S, Lin HZ, Chatham J, Chacko VP, Hoek JB, WalajtysRode E, Rashid A, Chen C-H, Huang C-C et al. 1999 Obesity induces expression of uncoupling protein-2 in hepatocytes and promotes liver ATP depletion. Journal of Biological Chemistry 274 5692-5700.

Fink BD, Hong YS, Mathahs MM, Scholz TD, Dillon JS \& Sivitz WI 2002 UCP2-dependent proton leak in isolated mammalian mitochondria. Journal of Biological Chemistry 277 3918-3925.

Garthwaite TL, Martinson DR, Tseng LF, Hagen TC \& Menahan LA 1980 A longitudinal hormonal profile of the genetically obese mouse. Endocrinology 107 671-676.

Ho PW, Chan DY, Kwok KH, Chu AC, Ho JW, Kung MH, Ramsden DB \& Ho SL 2005 Methyl-4-phenylpyridinium ion modulates expression of mitochondrial uncoupling proteins 2,4 , and 5 in catecholaminergic (SK-N-SH) cells. Journal of Neuroscience Research 81 261-268.

Ito E, Ozawa S, Takahashi K, Tanaka T, Katsuta H, Yamaguchi S, Maruyama M, Takizawa M, Katahira H, Yoshimoto K et al. 2004 PPAR-gamma overexpression selectively suppresses insulin secretory capacity in isolated pancreatic islets through induction of UCP-2 protein. Biochemical and Biophysical Research Communications 324 810-814.

Joseph JW, Koshkin V, Zhang CY, Wang J, Lowell BB, Chan CB \& Wheeler MB 2002 Uncoupling protein 2 knockout mice have enhanced insulin secretory capacity after a high-fat diet. Diabetes $\mathbf{5 1}$ 3211-3219.

Joseph JW, Koshkin V, Saleh MC, Sivitz WI, Zhang CY, Lowell BB, Chan CB \& Wheeler MB 2004 Free fatty acid-induced beta-cell defects are dependent on uncoupling protein 2 expression. Journal of Biological Chemistry 279 51049-51056.

Kaplan ML \& Leveille GA 1981 Development of lipogenesis and insulin sensitivity in tissues of the $o b / o b$ mouse. American Journal of Physiology. Endocrinology and Metabolism 240 E101-E107.

Kassis N, Bernard C, Pusterla A, Casteilla L, Penicaud L, Richard D, Ricquier D \& Ktorza A 2000 Correlation between pancreatic islet uncoupling protein-2 (UCP2) mRNA concentration and insulin status in rats. International Journal of Experimental Diabetes Research 1 185-193.

Kibenge MT \& Chan CB 1995 Identification of biochemical defects in pancreatic islets of $f a / f a$ rats: a developmental study. Obesity Research 3 171-178.

Kim M-J, Ryu GR, Kang J-H, Sim SS, Min DS, Rhie D-J, Yoon SH, Hahn SJ, Jeong I-K \& Hong K-J 2004 Inhibitory effects of epicatechin on interleukin1 [beta]-induced inducible nitric oxide synthase expression in RINm5F cells and rat pancreatic islets by down-regulation of NF-[kappa]B activation. Biochemical Pharmacology 681775.

Kjorholt C, Akerfeldt MC, Biden TJ \& Laybutt DR 2005 Chronic hyperglycemia, independent of plasma lipid levels, is sufficient for the loss of $\beta$-cell differentiation and secretory function in the $d b / d b$ mouse model of diabetes. Diabetes $\mathbf{5 4}$ 2755-2763. 
Koshkin V, Wang X, Scherer PE, Chan CB \& Wheeler MB 2003 Mitochondrial functional state in clonal pancreatic $\beta$-cells exposed to free fatty acids. Journal of Biological Chemistry 278 19709-19715.

Krauss S, Zhang C-Y, Scorrano L, Dalgaard LT, St-Pierre J, Grey ST \& Lowell BB 2003 Superoxide-mediated activation of uncoupling protein 2 causes pancreatic $\beta$ cell dysfunction. Journal of Clinical Investigation 112 1831-1842.

Lakey JR, Young AT, Pardue D, Calvin S, Albertson TE, Jacobson L \& Cavanagh TJ 2001 Nonviral transfection of intact pancreatic islets. Cell Transplantation 10 697-708.

Lameloise N, Muzzin P, Prentki M \& Assimacopoulos-Jeannet F 2001 Uncoupling protein 2: a possible link between fatty acid excess and impaired glucose-induced insulin secretion? Diabetes 50 803-809.

Laybutt DR, Sharma A, Sgroi DC, Gaudet J, Bonner-Weir S \& Weir GC 2002 Genetic regulation of metabolic pathways in beta-cells disrupted by hyperglycemia. Journal of Biological Chemistry 277 10912-10921.

Lee S, Lee H, Kim S, Lee IK \& Song DK 2004 Enhancing effect of taurine on glucose response in UCP2-overexpressing beta cells. Diabetes Research and Clinical Practice 66 S69.

Medvedev AV, Robidoux J, Bai X, Cao W, Floering LM, Daniel KW \& Collins S 2002 Regulation of the uncoupling protein-2 gene in INS-1 beta-cells by oleic acid. Journal of Biological Chemistry 277 42639-42644.

Menahan LA 1983 Age-related changes in lipid and carbohydrate metabolism of the genetically obese mouse. Metabolism 32 172-178.

Milne HM, Burns CJ, Squires PE, Evans ND, Pickup J, Jones PM \& Persaud SJ 2005 Uncoupling of nutrient metabolism from insulin secretion by overexpression of cytosolic phospholipase A(2). Diabetes 54 116-124.

Moynihan KA, Grimm AA, Plueger MM, Bernal-Mizrachi E, Ford E, Cras-Meneur C, Permutt MA \& Imai S-I 2005 Increased dosage of mammalian Sir2 in pancreatic Bcells enhances glucose-stimulated insulin secretion in mice. Cell Metabolism 2105.

Patane G, Anello M, Piro S, Vigneri R, Purrello F \& Rabuazzo AM 2002 Role of ATP production and uncoupling protein-2 in the insulin secretory defect induced by chronic exposure to high glucose or free fatty acids and effects of peroxisome proliferator-activated receptor-gamma inhibition. Diabetes $\mathbf{5 1}$ 2749-2756.

Pecqueur C, Alves-Guerra M-C, Gelly C, Levi-Meyrueis C, Couplan E, Collins S, Ricquier D, Bouillaud F \& Miroux B 2001 Uncoupling protein 2 , in vivo distribution, induction upon oxidative stress, and evidence for translational regulation. Journal of Biological Chemistry 276 8705-8712.

Pedersen SB, Bruun JM, Kristensen K \& Richelsen B 2001 Regulation of UCP1, UCP2 and UCP3 mRNA expression in brown adipose tissue, white adipose tissue, and skeletal muscle in rats by estrogen. Biochemical and Biophysical Research Communications 288 191-197.

Petersen KF, Dufour S \& Shulman GI 2005 Decreased insulin-stimulated ATP synthesis and phosphate transport in muscle of insulin-resistant offspring of type 2 diabetic patients. PLoS Medicine 2 e233.

Poitout V \& Robertson RP 2002 Minireview: secondary B-cell failure in type 2 diabetes-A convergence of glucotoxicity and lipotoxicity. Endocrinology 143 339-342.

Porter RK, Joyce OJ, Farmer MK, Heneghan R, Tipton KF, Andrews JF, Mc Bennett SM, Lund MD, Jensen CH \& Melia HP 1999 Indirect measurement of mitochondrial proton leak and its application. International Journal of Obesity and Related Metabolic Disorders 23 (Suppl 6) S12-S18.
Rashid A, Wu TC, Huang CC, Chen CH, Lin HZ, Yang SQ, Lee FY \& Diehl AM 1999 Mitochondrial proteins that regulate apoptosis and necrosis are induced in mouse fatty liver. Hepatology 29 1131-1138.

Saleh MC, Wheeler MB \& Chan CB 2002 Uncoupling protein-2: evidence for its function as a metabolic regulator. Diabetologia 45174.

Sesti G, Cardellini M, Marini MA, Frontoni S, D’Adamo M, Del Guerra S, Lauro D, De Nicolais P, Sbraccia P, Del Prato S et al. 2003 A common polymorphism in the promoter of UCP2 contributes to the variation in insulin secretion in glucose-tolerant subjects. Diabetes 52 1280-1283.

Shimabukuro M, Koyama K, Chen G, Wang M-Y, Trieu F, Lee Y, Newgard CB \& Unger RH 1997 Direct antidiabetic effect of leptin through triglyceride depletion of tissues. PNAS 94 4637-4641.

Sorhede Winzell M, Svensson H, Enerback S, Ravnskjaer K, Mandrup S, Esser V, Arner P, Alves-Guerra M-C, Miroux B, Sundler F et al. 2003 Pancreatic $B$-cell lipotoxicity induced by overexpression of hormonesensitive lipase. Diabetes 52 2057-2065.

Tassava TM, Okuda T \& Romsos DR 1992 Insulin secretion from $o b / o b$ mouse pancreatic islets: effects of neurotransmitters. American Journal of Physiology 262 E338-E343.

Tordjman K, Standley KN, Bernal-Mizrachi C, Leone TC, Coleman T, Kelly DP \& Semenkovich CF 2002 PPAR alpha suppresses insulin secretion and induces UCP2 in insulinoma cells. Journal of Lipid Research 43 936-943.

Wang H, Maechler P, Antinozzi PA, Hagenfeldt KA \& Wollheim CB 2000a Hepatocyte nuclear factor $4 \alpha$ regulates the expression of pancreatic betacell genes implicated in glucose metabolism and nutrient-induced insulin secretion. Journal of Biological Chemistry 275 35953-35959.

Wang H, Antinozzi PA, Hagenfeldt KA, Maechler P \& Wollheim CB $2000 b$ Molecular targets of a human HNF1 $\alpha$ mutation responsible for pancreatic B-cell dysfunction. EMBO Journal 19 4257-4264.

Wang X, Li H, De Leo D, Guo W, Koshkin V, Fantus IG, Giacca A, Chan CB, Der S \& Wheeler MB 2004 Gene and protein kinase expression profiling of reactive oxygen species-associated lipotoxicity in the pancreatic $B$-cell line MIN6. Diabetes 53 129-140.

Yamashita T, Eto K, Okazaki Y, Yamashita S, Yamauchi T, Sekine N, Nagai R, Noda M \& Kadowaki T 2004 Role of uncoupling protein-2 up-regulation and triglyceride accumulation in impaired glucose-stimulated insulin secretion in a beta-cell lipotoxicity model overexpressing sterol regulatory element-binding protein-1c. Endocrinology 145 3566-3577.

Zhang CY, Baffy G, Perret P, Krauss S, Peroni O, Grujic D, Hagen T, Vidal-Puig AJ, Boss O, Kim YB et al. 2001 Uncoupling protein-2 negatively regulates insulin secretion and is a major link between obesity, beta cell dysfunction, and type 2 diabetes. Cell 105 745-755.

Zhou YT, Shimabukuro M, Koyama K, Lee Y, Wang MY, Trieu F, Newgard CB \& Unger RH 1997 Induction by leptin of uncoupling protein-2 and enzymes of fatty acid oxidation. PNAS 94 6386-6390.

Received 22 December 2005

Received in final form 25 April 2006

Accepted 26 May 2006

Made available online as an Accepted Preprint

16 June 2006 